\title{
TECHNIKAI HALADÁS ÉS MUNKA - TÖRTÉNELMI ÉS GLOBÁLIS MEGKÖZELÍTÉSBEN
}

\section{TeChNOLOgical AdVANCE AND LABOUR - A Histo- RICAL AND GLOBAL APPROACH Artner AnNamária ${ }^{1}$}

A cikk a technikai haladás munkaeröpiacra gyakorolt hatásával foglalkozik a fóáramú megközelítéstöl némiképpen eltérően, történelmi és globális perspektívából. Elöször röviden áttekinti az eddigi technikai és ipari forradalmakat a munkára gyakorolt hatásuk szempontjából, majd a technika és a társadalmi viszonyok összefüggését tárgyalja. Megvizsgál néhány közkézen forgó félreértést és pontatlanságot a termelékenységnövekedés és a piaci konkurenciaharc, az automatizáció és a termeléskitelepítés, valamint a technológiai fejlödés és a munkaerőpiaci feszültségek viszonyával kapcsolatban, s végül az oktatás társadalmi funkciójáról is szól.

The author examines the effects of technological advance on the labour market from a non-mainstream, historical and global perspective. First, she presents an overview of the industrial revolutions and their impact on labour and employment and discusses the relation between production techniques and social relations. Then she illuminates some common misunderstandings in connection with the relation of competitiveness and productivity, labour and wage labour and the technology and labour market tensions. Finally, she deals with the social function of education.

\section{BEVEZETÉS}

Korunk kurrens témája a hálózatba kapcsolt, mikro-, nano-, bio- és zöldtechnológiák munkahely-megszüntető hatása, és a munkaerő képességeivel szemben támasztott állítólag új követelmények. Az ehhez lényegileg hasonló változások és félelmek egyidősek az ipari forradalmak történetével. Elég, ha a misztikus, a legenda szerint Robin Hoodhoz hasonlóan a sherwoodi erdőben lakó Ludd tábornokra és gépromboló követőire gondolunk, akik a XVIII. század végén a gépesítésben látták gyötrelmeik - a munkanélküliség - forrását. De ha azt hisszük, hogy ez csak a régmúlt tanulatlan embereire jellemző okoskodás, akkor jó, ha felidézzük, hogy 1968-ban tudósok és iparmágnások összeültek, hogy megvitassák az emberiség előtt álló, „egymással összekapcsolódó kihívásokat”, amelyek „megértése a jövő tervezése szempontjából lényegbevágó”. Rendszeres öszszejövetelükből született meg a Római Klub. Munkájukhoz több jelentés is készült. Az első a híres „A növekedés határai” 1972-ben, amelynek tudós írói már akkor figyelmeztettek, hogy ha a dolgok úgy mennek tovább, mint eddig („business as usual”), akkor a világrendszer ökológiailag és társadalmilag 50-100 éven belül fenntarthatatlan lesz [Meadows et al., 1972]. Aztán még több jelentés

\footnotetext{
${ }^{1}$ tudományos fömunkatárs, KRTK Világgazdasági Intézet; artner.annamaria@krtk.mta.hu DOI: 10.14267/RETP2019.04.01
} 
következett, a sorban a 13. éppen korunk csúcstechnológiai alapzatának, a mikroelektronikának társadalmi hatásaival foglalkozott [Friedrichs - Schaff, 1982, 1984]. A szerzők már ekkor azt latolgatták, vajon hogyan fognak új munkahelyet találni a számítógépek elterjedésével feleslegessé váló irodai dolgozók. Tudjuk, azóta az irodai munkák ugyancsak megszaporodtak...

Érdekes hasonlattal írja le a holisztikus, térben és időben kiterjedő gondolkodás hiányát Kurt Vonnegut Az ötös számú vágóhíd c. regényében. A főhős, Billy Pilgrim a Tralfamador bolygóról „érkező" látogatóktól megtudja, hogy ők nem csillogó pontok tömkelegének látják a világegyetemet, mint az ember, hanem „pontosan látják, hogy a múltban hol volt minden csillag, és azt is, hogy hova megy, így hát számukra az eget amolyan vékony, világító üvegszálak szövik át" [Vonnegut, 1969:88]. A tralfamadoriak számára úgy jelenik meg az idő, ahogy egy táj: hegylánccal, sivataggal, szakadékkal, előre és hátra, közel s távol, az eget hasító madarakkal, lábuk alatt a kavicsokkal. Az emberek ellenben úgy látják mindezt, mintha fejükön egy acélbura lenne, azon csak egy kicsi nyílás, amelyhez egy kétméteres csövet forrasztottak, és az egészet egy sínen gördülő kocsira rögzítették volna. A fejük nem mozdulhat, míg a kocsi halad, hol gyorsan, hol szélsebesen, hegynek föl, völgynek le, de az ember mindig csak egyetlen pöttyöt lát a világból, és nem marad más választása, bármit lát is, minthogy azt mondja: „Ez az élet.” [Vonnegut, 1969:116].

A társadalmi folyamatok időben és térben való kiterjedtségük, a jelenség szintjén többnyire nem megragadható ok-okozati összefüggéseik miatt persze nehezen leírhatók. De, mint Marx mondta, minden tudomány felesleges volna, ha a dolgok megjelenési formája és lényege közvetlenül egybeesne [Marx, A töke III., 1894:770]. Az alábbiakban sem fogunk tudni teljes képet nyújtani a technológia és a munka kapcsolatáról, de mindenesetre igyekszünk felvillantani annak történelmi és globális összefüggéseit és különösen a termelőmód általi meghatározottságát.

Elöször a technikai forradalmak szakaszairól és a munkára gyakorolt hatásáról lesz szó, aztán a technika és a társadalmi viszonyok összefüggéseiről, s végül pedig néhány közkeletű félreértésről vagy pontatlanságról a technikai haladás és a munka termelékenysége, mennyisége és milyensége témakörében. Cikkünket mindezek tükrében a tanulás szerepére vonatkozó gondolatok zárják.

\section{A TECHNIKAI FORRADALMAK ÉS A MUNKA}

Ha az emberiség őstörténetétől kezdve kívánjuk a tudomány, illetve a termelési eszközök egymással szorosan összefüggő fejlődésének lépcsőfokait meghatározni, biztosan meg kell jelölnünk a kőpattintást és vele a tüz elsajátítását (már jóval a ma élő ember, a Homo sapiens sapiens megjelenése előtt, kb. 300-350 ezer éve [Szemjonov, 1973:174-175], a fémek felfedezését, kezdve a rézzel kb. 11 ezer évvel ezelőtt (kiterjedt használatát azonban csak a mezőgazdaság hozta el). A sorban a földmüvelésnek mintegy nyolcezer évvel ezelötti felfedezése következhetne - minden bizonnyal a nőknek köszönhetően, akikre az első, nemek szerinti munkamegosztásban a magvak gyüjtögetésének feladata jutott, ami magával hozta a munka fogalmának megjelenését.

„A vadászgazdálkodás korában a munkát nem tekintették az élet többi vonatkozásától elválasztható, külön tevékenységnek. Minden cselekedet szorosan összefüggött a következményeivel. Az ember azért vadászott, hogy élelmet szerezzen, amit hozzátartozóival együtt hamarosan el is fogyasztott. De a mezőgazdaságban már nagy időbeli távolság volt aközött, amit az ember cselekedett és amit cselekedetéért kapott, továbbá számos önmagában véve unalmas és fárasztó tennivaló akadt, amiből teljesen hiányzott a vadászat izgalma." [Bernal, 1963:59]. 
Továbbhaladva az időben, a jelentősebb technikai újítások után kutatva meg kellene említenünk az írás kialakulását (Egyiptom és Mezopotámia kb. 3.500 éve), ezzel körülbelül egyidőben és ugyanott a vitorla, valamint a kerék felfedezését, továbbá a vasolvasztás megjelenését (valahol a Kaukázustól délre) [Bernal, 1963:93]. Mindez a városok (elsőként talán Jerikó) kialakulásához vezetett, amely a tudományos és technikai innovációk egész sorának adott lendületet. Megindult az osztálytagozódás is, amely alighanem a papság kiemelkedésével kezdődött, lévén a faluközösségi lét kezdeteitől a papok feladata volt a termékfelesleg elosztása (ennek során sikerült a termékek egyre nagyobb részét visszatartaniuk „isten” számára) [Bernal, 1963:65-67].

Az újítások korát a háborúk és a technikai pangás időszaka követte, ekkor inkább csak az addigi eljárások és eszközök tökéletesítése zajlott. Sem a kor uralkodó osztályai, sem közvetlen termelői, a rabszolgák, és a velük szinte egy sorban kezelt és megvetett szabad munkások vagy a röghöz kötött jobbágyok nem voltak érdekeltek a technikai fejlődésben. Ezek az évezredek is gyarapították az emberiség tudományos és kulturális örökségét (például a hellén kultúra vagy a reneszánsz), de az újabb szintlépéshez a vallás és a tudomány elválására volt szükség. Ezt olyan, átütőnek ritkán nevezett, pedig valójában nagyon is kulcsjelentőségű eszközök tették lehetővé, mint például az 1600-as évek elején megjelenő mikroszkóp vagy a távcső (gondoljunk a vérkeringés leírására vagy Kopernikusz és Galilei küzdelmére az egyházzal a heliocentrikus világnézet kapcsán). Érdekes módon a távcsövet állítólag véletlenül fedezték fel a szemüveggyártás melléktermékeként. Az elkészítéséhez szükséges üveglencsék már háromszáz éve rendelkezésre álltak, mégsem foglalkozott vele senki, míg a holland Lippershey mühelyében egy játszadozó gyerek két szemüveglencsét egymás mögé nem tett [Bernal, 1963:268]. A szív és a Nap (az emberi létezés belső és külső centrumai) központi szerepének felfedezése derékba törte az uralkodó világképet és az egyház hatalmát, de a tudomány ettől még nem vált termelőerővé. Ehhez „meg kellett teremteni a tudomány kapcsolatát a kereskedők, hajósok, iparüzők, államférfiak, valamint a korai, még haladó kapitalisták világával” [Bernal, 1968:278]. A XVII. század folyamán ez végbe is ment, a newtoni világkép felváltotta az arisztotelészit.

Egy átmeneti, pangási időszak után következett be az ipari forradalom kora. A kifejezést Engels használta elöször „A munkásosztály helyzete Angliában” című szociográfiai müvében, amelyet osztályelhagyó migráns értelmiségiként közvetlen empirikus kutatás (terepmunka) alapján írt Angliában 1844-ben.

„Az angol munkásosztály története a XVIII. század második felében, a gözgép és a gyapotfeldolgozó gépek feltalálásával kezdődik. Ezek a találmányok indították meg, mint tudjuk, az ipari forradalmat, azt a forradalmat, amely egyszersmind az egész polgári társadalmat átalakította, $s$ amelynek világtörténelmi jelentőségét csak most kezdik felismerni” [Engels, 1845 (1958):223].

Az Engels által jelzett ipari forradalmat, amely a sorban csak az elsőnek bizonyult, a James Watt-féle gőzgép (1769), a „Fonó Jenny”-nek nevezett 8 orsós fonógép (James Hargreavest 1764), valamint a vízzel hajtott, folyamatos fonógép (Richard Arkwright, 1769) szimbolizálja. Ezek a találmányok az ember fizikai erejét és ujjainak ügyességét váltották ki. És mégis, mit látunk? Az ipari munkásság létrejötte éppen ezekkel a találmányokkal, az ipar gépesítésével függ össze:

„A gyorsan terjeszkedő iparnak munkáskezekre volt szüksége; a munkabér emelkedett, és ennek következtében a mezőgazdasági kerületekből a munkások csapatostul vándoroltak a városokba. A népesség rohamosan gyarapodott és ez a gyarapodás majdnem kizárólag a proletárok osztályát növelte” (Engels, 1845 (1958):235]. 
Mivel a mezőgazdaságban feleslegessé vált, illetve onnan elüzött, megélhetésüket elvesztő tömegek a városokba vándoroltak, egyszerre nőtt az ipari munkásság létszáma és a munkanélküliség. Így e folyamat - az emelkedő, de még így is roppant alacsony bérek mellett - a nyomor fokozódásával is járt, amelyről Engels mellett Polányi [1946, 2004] is plasztikus képet nyújtott.

„... a független munkás és a pauper ... Speenhamland idején már alig különbözött egymástól. ... A speenhamlandi törvény eltörlése lett a modern munkásosztály valódi születésnapja. ... Most (1834-től -A.A.) a kérelmezöre bízták, hogy eldöntse, vajon tényleg olyan végletesen nyomorog-e, hogy önként bemenekül egy olyan menedékhelyre, amelyet szándékosan irtózatossá tettek. ... 1834-ben indulásra kész volt az ipari kapitalizmus ... A speenhamlandi törvény ... [h] atályon kívül helyezésének idejére a dolgozó népesség hatalmas tömegei inkább lidércnyomásban kísértő szellemekre, mint emberi lényekre emlékeztettek. De ha a munkások fizikailag embertelenedtek el, a tulajdonos osztályok erkölcsileg alacsonyodtak le. Megszünt a keresztény társadalom hagyományos egysége, a tehetősek nem voltak hajlandók felelősséget vállalni embertársaik állapotáért. Kialakult a két nemzet. A gondolkodó elmék rémületére kiderült, hogy hihetetlen gazdagság elválaszthatatlan a hihetetlen nyomortól. ...

Érvényesülni kívánt a piac mechanizmusa, és követelte kiteljesítését: áruvá kellett tenni a munkaerö." [Polányi,1946, 2004:139-141]

(Speenhamland a város neve, ahol 1795-ben útjára indult az 1834-ig működő angliai segélyezési rendszer, amely nyomorszinten tartotta a béreket.)

Kizárólag a technikai változások tehát nem hordozták magukban a munkásosztály nyomorát: ehhez az „intézmények” (Polányi) vagyis a „felépítmény” (Marx) változásai kellettek, nemcsak Angliában.

Ahhoz, hogy az ipari forradalom egész Európában elterjedjen, politikai változásokra volt szükség. Ezt biztosította az 1789-es francia polgári forradalom, majd a napóleoni háborúk, melynek során a híres korzikai vérbe borította Európát, és amerre járt, a szabadelvü francia alkotmányt iktatta törvénybe. „Az a vihar, amely két évtizeden át zúgott Európa fölött, és aminek közepén Napóleon állott, az elöregedett építmények egész sorát eltüntette" [Tarlé, 1946:561]. Az új társadalmi rend felállásához persze további forradalmak és reformok kellettek, amelyekre az 1800-as évek derekán, a feudális reakciót (a Szent Szövetség felbomlását) követően került sor.

A második ipari forradalom, vagy inkább az ipari forradalom második szakasza az elöző fejlemények bázisán az 1870-es évektől ment végbe, és az első szakasz kiteljesítését jelentette a villamossággal és a robbanómotorral (1876). Ezek már a tömegtermelés bázisát adták. Ez a hullám is kéz a kézben járt a társadalmi változásokkal, amiket a nemzetállamok kialakulása és megszilárdulása, vagy a munkásság forradalmai $(1871,1917-19)$ és nem utolsósorban az első világháború jellemeztek. Ennek az időszaknak az elején születnek meg - nem függetlenül Párizsi Kommünben testet öltő, az uralkodó renddel szembeni új típusú fenyegetéstől - az első szociálpolitikai törvények is a bismarcki Németországban.

Az ipari forradalom következő hulláma - amit manapság harmadiknak neveznek, bár lényegét tekintve inkább a második - a XX. században zajlott, illetve zajlik ma is. Vezértechnológiája a félvezetőipar (a mikroelektronika, a korszerü információs technológiák magja), amihez egyéb technológiák sora kapcsolódik. Ezt az újabb forradalmat az különbözteti meg az előzőtől, hogy itt már az ember szellemi képességeit (a tervező-irányító-ellenőrző munkát) váltja ki a gép. Ezzel a tudomány valóban a mezőgazdasági és ipari termelés - sőt sok egyéb szolgáltatás és társadalmi funkció - irányító erejévé, közvetlen termelőerővé válik: a tudományos kutatások végső célja, 
hogy termékben manifesztálódjanak, a kutatás a fejlesztés társa, s a kettő együtt vállalati (vagy a vállalatokat segíteni hivatott állami) funkciókká lesz. Ezért szokták ezt a forradalmat „tudományos-technológiai" forradalomnak nevezni, melyben az egyéni feltaláló ötletességét a tervszerü tudományos kutatás helyettesíti [Bernal, 1963:450, 454].

Ennek az új, tudományos-technológiai forradalomnak az alapjai az atomfizika, a tranzisztor (1946), az integrált áramkör (1954) illetve a mikroprocesszor (1971). Meghatározó technológiája miatt hívják „digitális” vagy „információtechnológiai” forradalomnak is. Kifejlődésének társadalmi alapzatát a jóléti rendszerek adták az 1970-es években, ahol az állam a kutatás-fejlesztésben is közvetlenebb szerepet vállalt.

E forradalom második szakasza, amelyben a digitális technológiák integrálják az újabb technológiák sorát (nano-, bio-, zöld, stb.), a világháló (WorldWideWeb) 1991-es indulásával vette kezdetét. Ezt a szakaszt ma az Ipar 4.0 kifejezéssel illetik, ami jelzi a tudomány közvetlen termelésben játszott szerepéről korábban elmondottakat. Ezek a hálózatba integrált technológiák („Internet of things”) már nemcsak a tervezés és gyártás számítógépes irányítását (CAD, CAM), a 3D nyomtatást, vezeték nélküli autókat, okos házakat és okos infrastruktúrát és a robotika széleskörü alkalmazását jelentik, hanem a mesterséges intelligencia megjelenésével már az ember kombináló, szintetizáló, tanuló képességének kiváltására, helyettesítésére is képesek. A munkát végző embert tehát a gépek számottevően tehermentesítik még a felelősségteljes (pl. irányító, ellenőrző) pozíciókban is.

\section{TECHNIKAI HALADÁS ÉS TÁRSADALMI VISZONYOK}

Ezek az átlagember számára sci-fibe illő, mégis valóságos fejlemények, mint minden ismeretlen, befolyásunkon fölül álló dolog, félelmet keltenek. Az aggodalmak epicentrumában a munkahelyek elvesztésének réme áll, pedig már most is temérdek olyan munka van, amely lelketlensége, monotonitása vagy veszélyessége miatt nem embernek való. E ponton keveredik a munka és bérmunka fogalma, s valójában az utóbbi, vagyis a bért, megélhetést biztosító munka elvesztésével kapcsolatos félelmek kerekednek felül a józan észen, ami örömmel fogadná, hogy a gépek szabadidővel ajándékozzák meg az embert. Pontosabban csak ajándékozhatnák. Mert a bérmunkára épülő gazdasági-társadalmi rendszerben a szabadidő csak reziduum, maradvány, és nem cél. Ha eluralja a létet munkanélküliség formájában, az maga a rettenet - legalábbis a termelőeszközökkel nem rendelkező, s így csak munkaerejük eladásából megélni képes tömegek számára.

Persze vannak olyan munkakörök is, amelyek izgalmasabbak, s ma még nehezen hihetö, hogy a gépek ezeket a feladatokat is átvehetik az embertől. Ilyen a kutatás-fejlesztés: vajon a mesterséges intelligencia rendelkezik-e intuícióval, amely a felfedezés elengedhetetlen feltétele? Vagy az ápolás: tud-e a gép szeretni, van-e empátiája? A szórakoztatóipar és a múvészetek, újságírás: van-e a gépnek humora, tud-e gúnyolódni, sorok között olvasni/írni, kétértelmű vagy képes beszédet alkotni, azt megérteni? Végül, de nem utolsósorban: a politika a maga speciális követelményeivel vajon nyitva áll-e a gépek előtt? Van-e a gépnek osztály-hovatartozása, amely meghatározná cselekedeteit? Tud-e hazudni? Mint látható, ezek mind nem technikai kérdések, amelyek arra utalnak, hogy a technika alkalmazását és hatását azok a társadalmi viszonyok és szereplök határozzák meg és korlátozzák be, amelyek közt és akik a technikát alkalmazzák.

Ezért amikor a technológiai változások kapcsán a munka (pontosabban az élömunka) kiváltásával járó foglalkoztatás-csökkenésről és szakemberhiányról, valamint az ezekkel járó negatív 
társadalmi hatásokról (munkanélküliség, szegénység, jövedelmi polarizáció) elmélkedik bármely tudomány, akkor bizonyos fokú csőlátásról tesz tanúbizonyságot. Vagy a történelmi tapasztalatok negligálása tekintetében, vagy a technológia primátusának, társadalmi-politikai viszonyokon felül állásának implicit tézisével, vagy azzal, hogy a piaci viszonyok anarchiájának explicit bírálata nélkül valamiféle „tervszerü” politikát javasol a kormányoknak a munkaerőpiac (a munkavállaló emberek) „alkalmazkodása” érdekében. Pedig az ellentmondás szembeötlő. A technológiai változások a piaci anarchia talaján, a konkurencia (értsd: profit-) viszonyoknak alávetve bontakoznak ki, vagy maradnak látensek (visszatartott és monopolizált felfedezések), és ehhez a hektikus, kiszámíthatatlan folyamathoz kellene „előrelátólag” és időben alkalmazkodnia az állami politikáknak és a dolgozóknak.

Erre a történelmietlen és technicista gondolkodásra példa a történész Harari, aki szerint a liberális politikai rendszerek a gőzgépek, olajfinomítók és a televíziók idején alakultak ki, s ezek a rendszerek nehezen tudják kezelni az új technológiákat. Harari technicizmusa kitűnik abból, hogy elfelejti megemlíteni egyfelől a gyarmatok és világháborúk, másfelől a munkásosztály mozgalmainak és forradalmainak a szerepét a „liberális” demokráciák kialakulásában és fenntartásában. Az ilyen szemlélet azt sugallja: van jó technika és van rossz, mintha a szike tehetne róla, hogy életet mentenek vagy oltanak ki vele. Harari úgy véli, hogy az információs és biotechnológia összekapcsolódása hamarosan emberek milliárdjait (sic!) szorítja majd ki a munkapiacról, és a tömeges munkanélküliség aláássa a szabadságot és az egyenlőséget [Harari, 2018: XII., 18.] A történelmi tapasztalatok szerint azonban - mint Engels fent idézett munkájából is láttuk, s mint azt másutt maga Harari is elismeri - az ipari forradalmak minden elveszített munkahely helyébe legalább egy újat hoztak. A szerző arra a következtetésre jut, hogy elsősorban a munkavállalóknak kell alkalmazkodniuk, és őket kell megsegíteni is. Ez a kormányok feladata például úgy, hogy a sokkhatás csökkentése érdekében lassítják az automatizáció folyamatát [Bagó, 2019:4].

Marx híres szerint mondása szerint minden történelmi esemény kétszer kerül színre, elöször, mint tragédia, másodszor, mint bohózat [Marx, 1852 (1962):105]. Polányi Károly több nyelven megjelent művében nagyon részletesen leírta, $s$ fentebb mi is idéztük, mivel járt a „munkaerőpiaci alkalmazkodás" lassításának jó szándékkal kövezett pokolba vezető útja a speemhamlandi rendszer formájában. Ehhez képest tényleg bohókás ötletnek tünik az automatizáció folyamatának lassítása.

Az OECD szintén az egyének és a kormányok felelősségét hangsúlyozza a változások monitorozásában, a megfelelő intézmények és a jövőbe látó („forward-looking”) politika kialakításában a szakmastruktúra, a munkaerőpiaci mobilitás és a regionális fejlesztés területén [OECD, 2017, 2018].

Mindebben persze sok a részigazság, amelyeket azonban célszerü a tudományos-műszaki és társadalmi fejlődés történelmi dinamikájának keretében vizsgálni.

\section{TECHNIKAI HALADÁS ÉS SZÜKSÉGLETEK}

Mindenekelőtt a technika és a szükségletek dialektikája érdemel figyelmet. A kielégítetlen szükségletek megszülik a kielégítésükhöz szükséges eszközök iránti igényt, ami újabb szükségleteket szül részben ezeknek az eszközöknek az elöállításával kapcsolatban, részben úgy, hogy a kielégített szükségletek bázisán a népesség száma, életkora nő, ismeretei gyarapodnak, egészsége javul, a korábbi szükségletek egy része eltünik és így az azok kielégítésre fordított idő felszabadul, teret kínálva új tevekénységeknek. (Például a mosógép szükségtelenné teszi a sulykolót, a teknőt vagy a lavórt és időt szabadít fel a házimunkából, ami új szükségletek kielégítését teszi lehetővé és új szükségleteket szül.) A technikai haladás és a szükségletek dialektikus kapcsolatának logikai és 
időbeli sémáját ábrázolja az 1. és a 2. ábra. Megjegyzendő, hogy a profitszempontoknak alávetett tömegtermeléssel eljutottuk a szükségletek szándékolt termelése korába, annak minden tovahaladó káros társadalmi, környezeti vonatkozásával együtt.

1. ábra A technikai haladás és a szükségletek dialektikája I. (Logika)

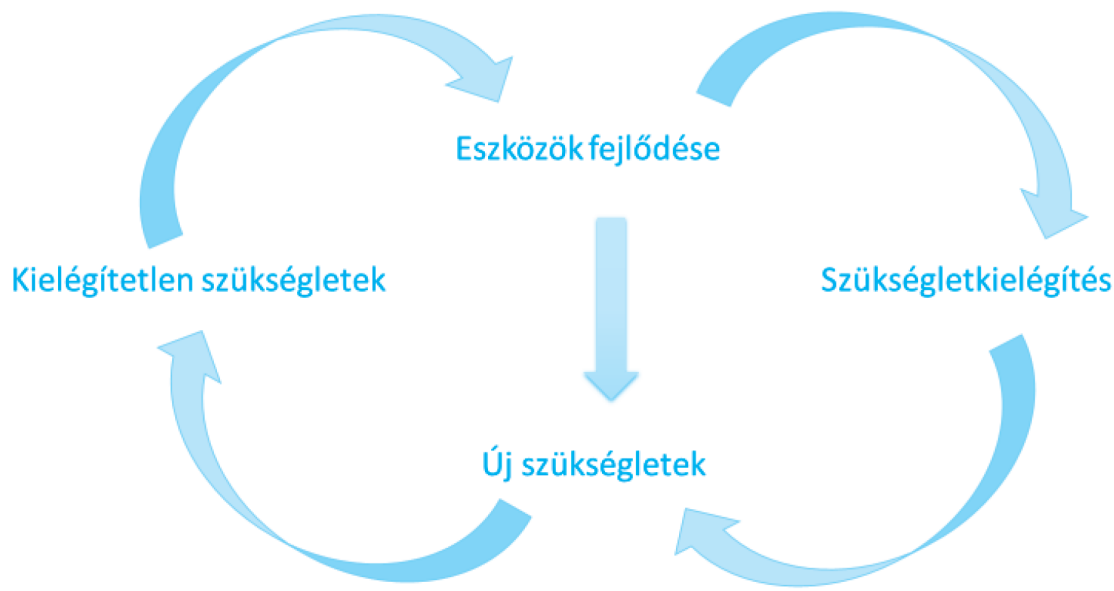

Forrás: a szerző saját szerkesztése

2. ábra A technikai haladás és a szükségletek dialektikája II. (Idő)

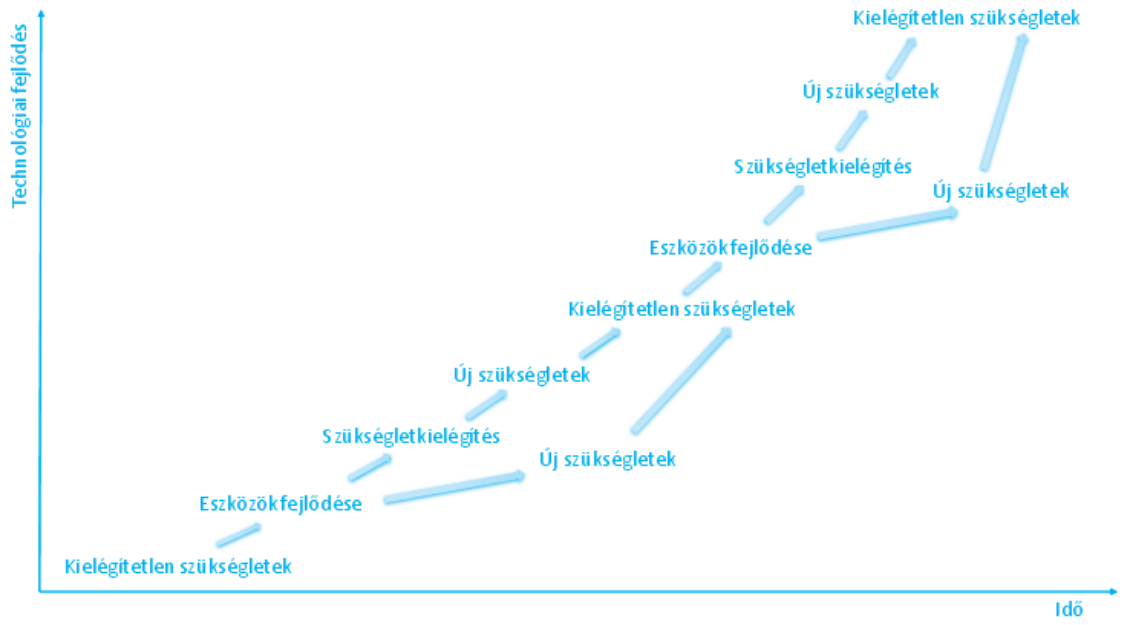

Forrás: a szerző saját szerkesztése

Másodszor hangsúlyozni kell, hogy a foglalkoztatás formái és a termelőmód éppily szorosan függ össze. Egyfelöl e formák a termelőmód függvényei, másfelől a formák változása utat nyit a termelömód változása előtt, amihez azonban az egész politikai intézményrendszer és a tulajdonviszo- 
nyok változása is kell. Mindez jól nyomon követhető Polányi híres művében, A nagy átalakulásban [Polányi, 2004]. Minden társadalomban a rendelkezésre álló munkaidő szabályozza a termelést, de a kapitalizmusban a profitnak alárendelten és válságokon keresztül. Innen ered, hogy az atipikus foglalkoztatási formák (már az új technológiákat megelőző, de azok segítségével kétségkívül felgyorsuló) terjedésének köszönhetően a munkaidő formális (törvényes) rövidülése együtt jár egyrészt a ténylegesen ledolgozott órák számának és/vagy a munka intenzitásának, és/vagy a készenléti időnek (a munkáltatóval, illetve a munkával való folyamatos összekapcsoltságnak, a „constant connectivity”-nek vagy a „24/7 availability”-nek) a növekedésével, másrészt a nagyon alacsony óraszámú és bizonytalan, prekárius foglalkoztatás terjedésével [Messenger, 2018].

E fenti termelőmód-alapú szemlélet segítségével félreértések és pontatlanságok egész sorát lehet felfedezni a regnáló fóáramú közgazdasági, szociológiai elemzések körében a technikai fejlödés és foglalkoztatás viszonyával kapcsolatban. Az alábbiakban ezek közül tekintünk át néhányat.

\section{NÉHÁNY FÉLREÉRTÉS ÉS PONTATLANSÁg}

Mindenekelőtt az a széles körben elfogadott állítás érdemel figyelmet, amely szerint a termelékenységnövekedést a piaci konkurencia idézi elő. Nem mondhatjuk azt, hogy a konkurenciaharcnak nincs szerepe. Ám a közelebbi vizsgálat azt mutatja, hogy a döntö mozzanat inkább a foglalkoztatók (tőketulajdonosok) és foglalkoztatottak (bérmunkások) közti „harc”. A konkurenciaharcban ugyanis nem a termelékenység (db/óra, kg/óra, $\mathrm{kW} /$ óra stb.), hanem a költséghatékonyság (az egységnyi munkaerőköltség) a lényeges, és ezt a munka árának alacsonyan tartásával (alacsony bérủ országokba településsel, túlmunkával stb.) is el lehet érni. A termelékenységnövelés csak az ultima ráció (ld. még Artner 2018b és 2019b), amit többnyire a foglalkoztatottak (bérmunkások) munkaidő-csökkentésért, béremelésért vagy jobb munkakörülményekért folyó (osztály-) harca kényszerít ki.

„Mihelyt a munkásosztály fokozatosan gyülemlő felháborodása rákényszerítette az államot, hogy a munkaidőt erőszakosan megrövidítse - írta Marx 1867-ben -, és mindenekelőtt a tulajdonképpeni gyár számára normál munkanapot írjon elö, tehát attól a pillanattól fogva, hogy a munkanap meghosszabbítása útján történő fokozott értéktöbblet-termelés egyszer s mindenkorra lehetetlenné vált, a tőke minden hatalmával és teljes tudatossággal rávetette magát a géprendszer gyorsított kifejlesztése útján történő relatív értéktöbblet-termelésre." [Marx, A tőke I. 1867:382. o.]

Korunk globalizált tőkepiacán a helyzet bonyolultabb, hiszen alkalom adódik a termelés alacsonyabb bérü országokba történő kitelepítésére, ezáltal ott nő a termelés, ahol olcsóbb a munkaerő. A társadalmi dinamika azonban ott is előbb-utóbb a bérek emelkedéséhez, a munkakörülmények javulásához vezet, $s$ ha már tovább nem lehet települni, akkor jön a technikai „upgrading” - többnyire a fejlettebb, magasabb bérü országokban már alkalmazott technika áttelepülésével. Testközelből látható mindez például a magyarországi autóipari transznacionális vállalatok stratégiáján.

A mesterséges intelligencia jelenléte ellenére a fejlett országokban a termelékenység alig emelkedett a 2010-es években, aminek Szalavetz [2019] szerint a mérési problémákon túl az alacsony termelékenységü szolgáltatások bővülése (Baumol-hatás) és a komplementer beruházások elma- 
radása mellett az lehet az oka, hogy a mesterséges intelligencia nem terjed olyan gyors ütemben, mint a kutatók várták. A szerző nem vizsgálja azonban a bérek alakulását, ami a beruházások elmaradását, lassúságát magyarázhatná. Pedig a képhez bizony meghatározó módon hozzátartozik, hogy a bérek a fejlett (OECD-) országok átlagában 1995 óta alaposan elmaradnak a termelékenység emelkedésétől, ami a bérarány (bér/GDP) csökkenésében is testet ölt. Sőt, a termelékenység-emelkedés üteme azokban az országokban volt a kisebb (átlagos vagy átlag alatti), ahol a bérek a legkevésbé nőttek, közel stagnáltak, mint például Kanada, Japán és az USA. [OECD, 2018:56].

Nem kell tehát attól tartani, hogy az automatizáció (robotizáció, mesterséges intelligencia) korában elveszti jelentőségét az alacsony bérü országokba irányuló termelés-kitelepítés. Ez a stratégia a profitorientált termelés ésszerű menekülési stratégiája a költséges beruházások elől. (Ismét magyarországi példát hozva: az Audi inkább Magyarországon fejleszt, bővít már évek óta még a 2019-es sztrájkkal kiharcolt béremelés után is, mint Németországban, hiszen a magyar bérköltségek még mindig jóval elmaradnak a német bérektől, ráadásul a vállalat még jelentős állami támogatásokat is kap. Ugyanez mondható el a Knorr-Bremsevel vagy a Mercedes-Benzzel kapcsolatban is.) A technológiák továbbra is hullámszerüen, a centrumból a perifériák felé áramolnak, és ezzel egyben újra is termelik a világgazdasági fejlettségi hierarchiát. Nemcsak azért, mert a mindenkori legmodernebb technológia többnyire a centrumban marad, hanem azért is, mert a technológiai létrán való feljebb lépés nem jelenti egyben az értékláncban való előrehaladást is: a felsőbb szintek az így keletkező hozzáadott érték növekményét elvonják [Szalavetz, 2013].

Ebből következően nem állja meg a helyét az az állítás sem, hogy mivel az automatizáció lehetővé teszi az upstream tevékenységek (tervezés, kutatás-fejlesztés) fejlett országokból fejlődőkbe telepítését, az utóbbiak felzárkózása gyorsul. Először is, van olyan tevékenység, ami kitelepül, van, ami nem - ez a profitabilitási számítások, valamint a technológia monopolizálására irányuló (szintén profit-érdekü) megfontolások függvénye. Másodszor, még a kitelepülés esetében sem marad kellö hozzáadott érték (értéktöbblet) a telephely-országban a felhalmozás és így az utolérés finanszírozására (ld. még Artner 2018a). Harmadszor, még ha az upstream tevékenységek kitelepülnek is és sor kerül valamiféle felhalmozásra, spin-off hatásra, a leányvállalati kereteken túlmutató fejlődésre az adott fogadó országban, akkor sem történik valódi „felzárkózás”. Inkább a tőkeexportőr fejlett ország, illetve transznacionális vállalat igényei szerinti, a fogadó perifériás, félperifériás ország nemzetgazdasági és társadalmi szükségleteihez, fejlődési igényeihez mérten strukturálisan torz fejlődésre kerül sor, mint arra Samir Amin több munkájában is felhívta a figyelmet [Amin, 1974, 2011]. A technikai fejlesztés költségei elől menekülő tőke a perifériákon növeli a foglalkoztatást, fokozatosan kiterjesztve a bérmunkarendszert a ma még érintetlen területekre is, megnyújtva a munkaigényes termelési eljárások életgörbéjét, s megmerevítve, illetve újratermelve a globális fejlettségi hierarchiát.

Az ILO [2019] szerint a globális munkaerőpiac 3,2 milliárd résztvevőjének több mint fele informális keretek között dolgozik, túlnyomó többségük (1,5 milliárd fö) tartozik a legbizonytalanabb státuszú sebezhető foglalkoztatottak (önfoglalkoztatók, családi vállalkozásban kisegítők) körébe. Ök képezik az üzemszerü bérmunkarendszer tartalékseregét. A bérből és fizetésből élő alkalmazottak („wage and salaried employment”) aránya az összes foglalkoztatotton belül az országok gazdasági fejlődésével együtt nő, s ez az elkövetkező években is így lesz. Jelenleg arányuk az alacsony jövedelmű országokban 19 százalék, a magas jövedelműekben 87 százalék [ILO, 2019:13]. A bérmunka megszünéséről tehát szó sincs, s éppen a mind modernebb termelési technológiák terjedése teszi lehetővé, hogy újabb és újabb tömegeket integráljanak a bérmunkarendszerbe. 
A kapitalista gazdaságban - ahol a profit a cél, az egységnyi munkaerö-csökkentés az eszköz és ultima rációként a munkavállalók érdekérvényesítése hatására előrehalad a gépesítés (automatizáció) is - egyszerre van jelen a munkahelyek megszűnésének és az új munkahelyek teremtésének tendenciája: a tőkének egyszerre érdeke az élőmunka arányának csökkentése, ami a profit rátáját emeli, és a termelés kiterjesztése, ami pedig a profit tömegére van jótékony hatással. Így tehát téves az új technológiáktól a munkahelyek tömeges megszünését várni, az ilyen jóslatokban még sincs hiány. 2015-ben egy kutatás azt találta, hogy az USA-ban a munkások 47 százalékát lehet automatákkal helyettesíteni. Más, 2016-os kutatások szerint az ASEAN-5-ben (Fülöp-szigetelek, Indonézia, Malajzia, Szingapúr, Thaiföld) a következő 20 évben a munkák 56 százaléka van veszélyben, az OECD-ben pedig a munkahelyek 9 százalékát szüntetheti meg az automatizáció. A Világbank ugyancsak 2016-ban pedig arról írt, hogy a fejlődő országokban a munkahelyek kétharmada automatizálható [Pastore et al., 2019:71].

A kiegyensúlyozottabb elemzések inkább evolúcióról beszélnek, s kevésbé pesszimisták a munka jövőjével kapcsolatban. Így például az ILO és az EU közös teamje által készített összegzés szerint a technológiai fejlődés legfeljebb a munkahelyek 10 százalékát tünteti el, másutt csak megváltoztatja a feladatokat és új munkalehetőségeket teremt, továbbá lehetővé teszi a termelékenység növekedését és a munka-magánélet mérleg javítását. Viszont fennáll a veszély, hogy az új munkahelyek nem lesznek kedvezőek a munkavállalókra, $s$ új kihívást jelent a prekárius (bizonytalan, kiskeresetü) munkák megjelenése és terjedése, amit az új információs technológiák megkönnyítenek [Pastore et al., 2019].

Az ún. „atipikus” munkák, amelyek a prekárius foglalkoztatási formák melegágyai, már az 1980-as évek óta egyre népszerűbbek a foglalkoztatók között, s nemcsak a válság óta: már az azt megelöző évtizedben az OECD-országokban keletkezett új munkahelyeknek is több mint a fele részmunkaidős, határozott időtartamú szerződés vagy önfoglalkoztatás (vagyis „,atipikus” munka) volt. Ebben a technika csak segédkezet játszott, a fő hajtóerőt a tőke globális mozgása iránti igény, s a kormányok ehhez igazodó deregulációs, liberalizációs politikája képezte [Artner, 2019a].

A munkaerőpiaci feszültségekért és kérdőjelekért tehát felesleges a technológiai fejlődést okolni. Munkanélküliség, megterhelő munkaintenzitás, monotónia, kiüresedés, elidegenedés a fejlett információs technológiák megjelenése előtt is volt, s ha ez igaz, akkor ezek felerősödésének okát is másutt kell keresni. Az elidegenedés alapja az árutermelés, mint azt már Marx kimutatta, így minél több társadalmi és egyéni létfunkció kerül a piac fennhatósága alá, annál tökéletesebb az elidegenedés is. Továbbá ha a termelékenység az automatizáció jóvoltából nő, az azt jelenti, hogy ugyanannyi használati értéket kevesebb idő alatt, vagy ugyanannyi idő alatt több használati értéket lehet előálítani. Ez a folyamat egyben azzal is jár, hogy a szükséges munka - a munkaerő újratermeléséhez szükséges áruk elóállításához szükséges idő - csökken. Az ezt jóval meghaladó munkaórát csak a mohó profitérdek indokolja. A technológia alkalmazásának módja, helye, ideje és társadalmi-természeti hatása a társadalmi viszonyok függvénye.

\section{ZÁRÓ GONDOLATOK}

A jövőt a ma fiataljai hordozzák és ők fogják elviselni. Ha aggódunk azért, mit hoz ez a jövő, főleg rájuk gondolunk. Ezért az újabb technológiák értése és az alkalmazásukra való képesség jogos elvárás a felnövekvő nemzedékekkel szemben. Csakhogy korunkban erre rávetül a piaci értékesíthetőség imperatívuszának árnya. 
A munkagazdaságtanban központi helyet foglal el a munkakínálat és a munkabér életciklus-modellje, s e keretekben kezelik az oktatást, képzést is. E nézetrendszer szerint a társadalmi egyenlőtlenségek csökkentéséhez jószerivel csak annyi kell, hogy az emberi tőkébe történő beruházások az életciklusokhoz igazodjanak, vagyis a gyerek a legfogékonyabb, korai életéveiben kapjon a legtöbbet abból, amit aztán mind a társadalom, mind ő maga a legjobb hozammal tud felhasználni. Ez ugyan jól hangzik, és tekintettel az első életévek tapasztalatainak meghatározó jellegére, sok benne az igazság. A probléma az, hogy ez az elmélet egyrészt két lábon járó áruvá változtatja az emberi képességeket (hiszen cél azok piaci szempontú fejlesztése), másrészt nagyvonalúan elhallgatja, hogy az ember mindenoldalú lény, képességeit az őt körülvevő társadalmitermészeti viszonyok befolyásolják, amelyeknek csak egy része az iskolarendszer vagy a család. Ez utóbbiakat pedig magukat is a társadalmi viszonyok határozzák meg, például azzal, hogy formális vagy informális módokon „elöírják” és a rendelkezésükre bocsátott eszközökkel, információkkal behatárolják számukra, hogy a gyermekek mely képességeit fejlesszék/fejleszthetik és melyeket hanyagolják, netán nyomják el. Egy példa: kooperáció vagy versenyszellem. Nehéz egyszerre mindkettőt kialakítani a gyermekben, hiszen végső soron szögesen ellentétes mentalitást igényelnek. Valamelyiknek szükségszerüen dominánssá kell válnia, együttes „erőltetésük” elkerülhetetlenül frusztrációt okoz.

Korunk technológiái lehetővé teszik, hogy a ismereteink és az utánunk következő nemzedékek ismeretei a világról mind sokoldalúbbá váljanak, és a valódi társadalmi szükségleteket magas fokon, kevés „kényszerüségből” végzett, „nemszeretem” munkával lehessen kielégíteni. Ezt semmiképpen sem a technológiák, hanem csakis azok alkalmazásának módja gátolhatja/gátolja. Mindenekelőtt pedig az a gondolkodásmód, amit az uralkodó ideológia az oktatáson keresztül is igyekszik a felnövekvő nemzedékek fejébe verni: a piaci, versenyszellemü, önös, profitérdekü gazdálkodás az emberi teljesítmény ösztönzésének és a gazdasági, technológiai haladásnak nemcsak egyedül lehetséges, hanem a legjobb módja is. Pedig ha ez így lenne, az ENSZ fenntartható fejlődési céljai már régen megvalósultak volna.

\section{Felhasznált irodalom}

Amin, Samir (1974): Accumulation and development: a theoretical model. Review of African Political Economy, 1(1): 9-26.

Amin, Samir (2011): The Trajectory of Historical Capitalism and Marxism's Tricontinental Vocation. Monthly Review, 01 February, 2011 https://monthlyreview.org/2011/02/01/the-trajectory-of-historical-capitalism-and-marxisms-tricontinental-vocation/

Artner Annamária (2018a): Is Catching Up Possible? The Example of Central and Eastern Europe. Science \& Society, 82(4): 502-530.

Artner Annamária (2018b): Marx 200 - Marx öröksége, a munka helyzete és a felzárkózás lehetősége a globális kapitalizmusban. Eszmélet Zsebkönyvtár. Budapest: Eszmélet Alapítvány.

Artner Annamária. (2019a): Aggasztó tendenciák az Európai Unió munkaerőpiacán. Statisztikai Szemle 96(4): 341-374.

Artner Annamária. (2019b): A technológiai változások és a munka. Munkaügyi Szemle 62(4): 6-13.

Bagó József (2019): A munka 2050-ben. Munkügyi Szemle 62(6): 2-5. https://drive.google.com/ file/d/17g5J0hZyxzRm5ERXyyJi0FLJR7X7a16K/view 
Bernal, John D. (1963): Tudomány és történelem. Gondolat, Budapest

Club of Rome (s.a.): History. https://www.clubofrome.org/about-us/history/

Engels, Friedrich. (1845 [1958]): A munkásosztály helyzete Angliában. MEM 2. Kossuth Könyvkiadó, Budapest.

Friedrichs, Günter - Schaff, Adam (ed.) (1982 [1984]): Mikroelektronika és társadalom. Áldás vagy átok. Jelentés a Római Klub számára. Statisztikai Kiadó Vállalat Budapest.

Harari, Yuval Noah (2018): 21 Lessons for the 21st Century. Jonathan Cape, London.

ILO (2019): World Employment and Social Outlook: Trends 2019. International Labour Office, Geneva.

Marx, Karl (1852 [1962]): Louis Bonaparte brumaire tizennyolcadikája. MEM 8. Kossuth Könyvkiadó, Budapest.

Marx, Karl (1978): A tőke. I-III. Budapest, Kossuth Könyvkiadó.

Meadows, D. H., Meadows, D. L., Randers, J. and Behrens, W. W. (1972): The limits to growth. A report for the Club of Rome's project on the predicament of mankind. Universe Books, New York.

Messenger, Jon (2018): Working time and the future of work. ILO Futre of Work Working Paper Series. International Labour Organization. https:/www.ilo.org/wcmsp5/groups/public/--dgreports/---cabinet/documents/publication/wcms_649907.pdf

OECD (2017): Enabling the Next Production Revolution: A Summary of Main Messages and Policy Lessons. Meeting of the OECD Councilat Ministerial LevelParis, 7-8 June 2017. OECD, Paris https://www.oecd.org/industry/C-MIN-2017-5-EN.pdf

OECD (2018): OECD Economic Outlook, Volume 2018 Issue 2. Chapter 2. Decoupling of wagesfrom productivity:what implicationsfor public policies? OECD, Paris. http://www. oecd.org/economy/outlook/Decoupling-of-wages-from-productivity-november-2018OECD-economic-outlook-chapter.pdf

Pastore, F., Gausas, S., Styczyńska, I. et al., EU and ILO (2019): Shaping the Future of Work. Study for the Committee on Employment and Social Affairs, Policy Department for Economic, Scientific and Quality of Life Policies, European Parliament, Luxembourg, http://www.europarl.europa.eu/RegData/etudes/STUD/2019/638407/IPOL_STU(2019)638407_EN.pdf

Polányi Károly (1946 [2004]): A nagy átalakulás. Napvilág Kiadó, Budapest.

Szalavetz Andrea (2013): Régi-új világgazdasági jelenségek a globális értékláncok tükrében: gondolatok Simai Mihály „A világgazdaság az 1980-as évek végén és az 1990-es évek főbb globális kérdései” címü müve kapcsán. In: Szanyi M. (szerk.): Válság és megújulás. Múlt, jelen és jövő a világgazdaságban. Akadémiai Kiadó, Budapest, 103-118. old.

Szalavetz Andrea (2019): Mesterséges intelligencia és technológiavezérelt termelékenységemelkedés. Külgazdaság 63(7-8): 53-79.

Szemjonov, Jurij I. (1973): Hogyan keletkezett az emberiség? Kossuth Könyvkiadó, Budapest

Tarlé, Jevgenyij (1946): Napóleon. Cserépfalvi könyvkiadó, Budapest.

Vonnegut, Kurt, J. (1969): Az ötös számú vágóhíd. Szépirodalmi Könyvkiadó, Budapest. 